\title{
Parvovirus Induced Thrombocytopenia-Case Report
}

\author{
*Burak Furkan Demir, Aysenur Karahan Meteris, Gokhan Yirgin, Mustafa Comoglu, Bilal Katipoglu and \\ Ihsan Ates
}

Department of Internal Medicine, Ankara Numune Training and Research Hospital,Turkey

Received: March 09, 2018; Published: March 21, 2018

*Corresponding author: Bilal Katipoglu, Department of Internal Medicine, Ankara Numune Training and Research Hospital, Sihhiye, 06100, Ankara, Turkey, Tel: 90312 5084552; Fax: +90 312 3113958; Email: drbilal07@gmail.com

\begin{abstract}
Thrombocytopenia is a common hematologic disorder. Major causes of thrombocytopenia are chronic liver diseases, immune thrombocytopenia, congenital platelet disorders, infections, bone marrow disorders, malignancy and drugs. Many of viral and bacterial infections may induce thrombocytopenia. A 30 year old previously healty man with thrombocytopenia due to parvovirus B19 infection is discussed here. Viral infections should be kept in mind as a cause of thrombocytopenia which is a common laboratory finding.
\end{abstract}

Keywords: Immune Thrombocytopenic Purpura; Parvovirus B19; Thrombocytopenia

\section{Introduction}

Thrombocytopenia is defined as a platelet count below the lower limit of normal (ie, <150,000/microL [150 x 109/L] for adults). Degrees of thrombocytopenia can be further subdivided into mild (platelet count 100,000 to $150,000 / \mathrm{microL}$ ), moderate (50,000 to $99,000 /$ microL) and severe $(<50,000 /$ microL $)$. Most common causes of thrombocytopenia are chronic liver diseases, immune thrombocytopenia, congenital platelet disorders , infections, bone marrow disorders, malignancy and drugs. Immune thrombocytopenic purpura is an acquired thrombocytopenia caused by autoantibodies against platelet antigens. It is one of the most common causes of thrombocytopenia in asymptomatic adults. ITP can develop in the context of other disorders (secondary ITP). Some cases of ITP are associated with preceding viral infections or less commonly bacterial infections. Antibodies against viral antigens may cross-react with normal platelet antigens.

A 30 year old previously healthy man admitted to emergency room with skin rashes. He had no chronic diesaese and any drug use. One week before he admitted to hospital he had had an upper respirotary flu like infection. After that his body rashes appeared. During this period he didnot have used any drugs. At presentation the patient did not have bleeding or any active symptom. He had skin rashes in all extremites. Blood samples revealed 5000/microL platelets, $15.6 \mathrm{mg} / \mathrm{dL}$ hemoglobin, 6800/microL white blood cells. Pseudothrombocytopenia was excluded with periferal blood smear. Kidney functions were in normal range in admission. LDH was a near the upper limit (292u/L). Liver enzymes were in normal range. In follow-up, the patient had epistaxis.
He was replaced with one unit of platelet suspension. Platelet count did not increase enough after platelet replacement. We exluded other possible causes of thrombocytopenia. Many of viral and bacterial antigenes runned including HIV, HCV, HBV, EBV, CMV, Herpes virus, Helicobacter pylori, Toxoplasma, ParvovirusB19, Brucella. Only Parvovirus B19 IgM resulted positive among them. Then we administirated intravenous immunglobulin (IVIG) treatment with $1 \mathrm{mg} / \mathrm{kg} /$ day dose for two days. After IVIG treatment platelets increased to $40000 / \mathrm{microL}$ in two days. His skin rashes disappared in three days after IVIG treatment. Platelet counts increased spontanously and reached normal range in about one week. In past there are some cases showed possible association between Parvovirus B19 and immune thrombocytopenia. Most cases were seen in childhood or immune compromised patients [13].

Our case is 30 years old man and he did not have immunosupression. The most commonly used agents for initial treatment of ITP are glucocorticoids and intravenous immunglobulin. Intravenous anti-RhD is a type of immune globulin that may be effective in patients who have $\mathrm{Rh}+$ blood group and do not have splenectomy history. We preferred IVIG treatment rather than glucocorticoids because of rapidly increase in platelet count needed for the patient who had epistaxis which might be recurrent. Parvovirus B19 is a rare cause of thrombocytopenia especially for non immunosuppressed adult patients. We point at non-common viral etiology of thrombocytopenia with this case report. Clinicians should be keep in mind that viruses like ParvovirusB19 might be a possible cause of thrombocytopenia in healty adults. 


\section{References}

1. Murray JC, Kelley PK, Hogrefe WR, McClain KL (1994) Childhood idiopathic thrombocytopenic purpura: association with human parvovirus B19infection. Am J Pediatr Hematol Oncol 16(4): 314-319.

2. Aktepe OC, Yetgin S, Olcay L, Ozbek N (2004) Human parvovirus B19 associated with idiopathic thrombocytopenic purpura. Pediatr Hematol Oncol 21(5): 421-426.

\section{CC) (i) This work is licensed under Creative}

Submission Link: https://biomedres.us/submit-manuscript.php
3. Van Elsacker Niele AM, Weiland HT, Kroes AC, Kappers Klunne MC (1996) Parvovirus B19 infection and idiopathic thrombocytopenic purpura. Ann Hematol 72(3):141-144.

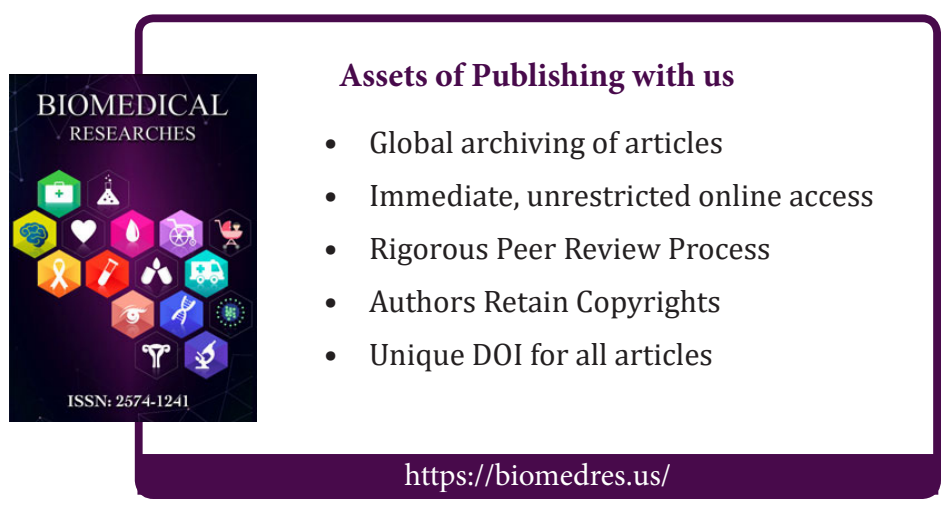

